\title{
Prevalence of hepatitis A virus infection in Afro-Brazilian isolated communities in Central Brazil
}

\author{
Aline G Kozlowski, Ana RC Motta-Castro**, Laura B Nascimento, Ágabo MC Silva, \\ Sheila A Teles*, Livia M Villar***, Ana MC Gaspar***, Regina MB Martins/ ${ }^{+}$
}

Instituto de Patologia Tropical e Saúde Pública *Faculdade de Enfermagem, Universidade Federal de Goiás, Caixa Postal 131, 74605-050 Goiânia, GO, Brasil **Departamento de Farmácia Bioquímica, Universidade Federal de Mato Grosso do Sul, MS, Brasil ***Departamento de Virologia, Instituto Oswaldo Cruz-Fiocruz, Rio de Janeiro, RJ, Brasil

To investigate hepatitis A virus (HAV) infection rates among isolated African-descendant communities in Central Brazil, 947 subjects were interviewed about demographic characteristics in all 12 isolated Afro-descendant communities existing in the state of Mato Grosso do Sul, Central Brazil, between March 2002 and November 2003. Blood samples were collected and sera were tested for HAV antibodies (total and IgM anti$H A V)$ by enzyme-linked immunosorbent assay. The overall prevalence of HAV infection was $75.6 \%(95 \%$ CI: 72.7-78.3), ranging from 55.4 to 97.3\%, depending on the communities studied. The prevalence of anti-HAV increased significantly with age, from $13.8 \%$ in the age $0-5$ age group to $96.6 \%$ in those older than 40 years. The findings point out an intermediate endemicity of HAV infection in some Afro-Brazilian isolated communities in Central Brazil. In addition, the high proportion of susceptible young subjects could be target of future HAV vaccination programs.

Key words: Afro-Brazilian - hepatitis A virus - prevalence

Worldwide, it is estimated that about 1.5 million clinical cases of hepatitis A occur each year (Lavanchy 2002). Transmission of hepatitis A virus (HAV) usually occurs by the faecal-oral route either through personto-person contact or ingestion of contaminated water or food. In developed countries, low prevalence of HAV infection has been found while in many developing ones; low income, low educational level, crowding and lack of access to safe drinking water, and sanitation facilities are associated with increased HAV infection prevalence. However, recent studies have shown a decline in antiHAV seroprevalence in Latin America, which has generally been explained by improvements in sanitary conditions, particularly in the access to clear water and to sewerage systems (Tapia-Conyer et al.1999, Tanaka 2000, Jacobsen \& Koopman 2004).

In Brazil, although hepatitis A is considered an endemic infection, some studies have shown a shift from high to intermediate endemicity in HAV infection epidemiological pattern, especially in South and Southeast regions (Vitral et al. 1998, 2006, Clemens et al. 2000, Santos et al. 2002). Furthermore, within this country, seroprevalence rates may vary by age, socioeconomic status, urbanization level and access to clean water as sanitation facilities (Vitral et al. 2006).

Financial support: $\mathrm{CNPq}$

${ }^{+}$Corresponding author: rbringel@ terra.com.br

Received 26 October 2006

Accepted 12 January 2007
African individuals were introduced in Brazil by slave trade. Some of them escaped from gold mines or farms, setting in remote valleys, to escape their masters. These runaway-slave descendants stayed in isolated communities, called "quilombos". The epidemiological status of HAV infection of these communities remains unknown. In this study, the prevalence of HAV infection among isolated African-descendant communities in Central Brazil was sought.

This study included 947 individuals living in all 12 isolated afro-descendants communities existing in the state of Mato Grosso do Sul, Central Brazil. Among them, seven communities were in rural areas: Furnas dos Dionísios, Jaraguari county $(\mathrm{n}=197)$, Furnas da Boa Sorte, Corguinho county $(\mathrm{n}=121)$, Malaquias, Camapuã county $(\mathrm{n}=83)$, Jerônimos, Terenos county $(\mathrm{n}=70)$, São Miguel, Maracaju county $(n=49)$, Furnas dos Baianos, Aquidauana county $(\mathrm{n}=42)$ and Quintinos, Pedro Gomes county $(\mathrm{n}=37)$; and five in urban areas: São Benedito, Campo Grande county $(\mathrm{n}=199)$, Orolândia, Rio Negro county $(n=49)$, São Miguel, Nioaque county $(n=48)$, Amarelinhos, Sidrolândia county $(\mathrm{n}=25)$, and Morro do Limão, Campo Grande county $(\mathrm{n}=27)$.

The population ranged in age from less than 1 to 108 years (average 29.8 years). Four hundred forty-nine were females and 498 were males. All these individuals had low socioeconomic (families with monthly income less than US\$ 200) and education levels (76\% had less than 8 years of formal education). In rural communities, the majority lived basically on subsistence agriculture or cattle-rising, and their houses had no sewage system, tap water service and access to electric power. The inhabitants of Amarelinhos community lived in rural area, but recently they have moved to Sidrolândia, a small city. In 
all but one (Orolândia) urban communities, sewage and water supply systems have been recently implemented.

The protocol used in the present study was approved by the Ethical Committee of the Federal University of Goiás. Informed consent was obtained from all participants (or their parents for children). In all communities nearly $75 \%$ of inhabitants were studied. Between March 2002 and November 2003, they were interviewed about demographic characteristics. Blood samples were collected from all individuals and sera were stored at $-20^{\circ} \mathrm{C}$.

All serum samples were tested by enzyme-linked immunosorbent assay (ELISA) for the presence of hepatitis A virus antibodies (total anti-HAV). Total anti-HAV positive samples were submitted to IgM anti-HAV detection (Organon TeKnika, Boxtel, The Netherlands) according to manufacturer's instructions.

Prevalence and 95\% confidence intervals (95\% CI) were calculated. Chi-square test and Chi-square for trend were undertaken to evaluate factors associated with HAV infection. Statistical significance was assessed at the 0.05 probability level in all analyses. Statistical evaluations were performed using Epiinfo program, version 2000 package developed by the Centers for Disease Control and Prevention (Atlanta, GA).

The prevalence of HAV infection by community is shown in Table I. Infection rates varied from 55.4 to 97.3\% in Malaquias and Quintinos communities, respectively. Of the 947 individuals, 716 were positive for anti$\mathrm{HAV}$, resulting in an overall HAV prevalence infection of $75.6 \%$ (95\% CI: $72.7-78.3)$.

The prevalence of HAV infection was higher in men $(52.6 \%)$ than in women $(47.4 \%)$, although the difference was not statistically significant $(p>0.05)$. There was a significant association for increasing infection rate with increasing age (Table II), rising from $13.8 \%$ in the 0-5 (95\% CI: 6.5-25.9) age group to $96.6 \%$ (95\% CI: 93.5-98.3) in those older than 40 years.

\section{TABLE}

Prevalence of hepatitis A virus infection in Afro-descendant isolated communities in Central Brazil

\begin{tabular}{lrcc}
\hline Community & $\mathrm{N}$ & $\begin{array}{c}\text { Prevalence } \\
(\%)\end{array}$ & $95 \%$ CI \\
\hline Malaquias & 83 & 55.4 & $44.1-66.2$ \\
Furnas da Boa Sorte & 121 & 59.5 & $50.2-68.2$ \\
Jerônimos & 70 & 64.3 & $51.7-75.1$ \\
Orolândia & 49 & 71.4 & $56.5-83.0$ \\
Furnas dos Dionísios & 197 & 75.6 & $68.9-81.3$ \\
Morro do Limão & 27 & 77.8 & $57.3-90.6$ \\
São Miguel (Maracaju) & 49 & 79.6 & $65.2-89.3$ \\
Furnas dos Baianos & 42 & 81.0 & $65.4-90.8$ \\
São Miguel (Nioaque) & 48 & 85.4 & $71.6-93.4$ \\
São Benedito & 199 & 87.9 & $82.4-92.0$ \\
Amarelinhos & 25 & 92.0 & $72.5-98.6$ \\
Quintinos & 37 & 97.3 & $84.2-99.9$ \\
\hline Total & 947 & 75.6 & $72.7-78.3$ \\
\hline
\end{tabular}

CI: confidence interval.
TABLE II

Hepatitis A virus global prevalence among Afro-Brazilian in isolated communities according to age

\begin{tabular}{lrcc}
\hline $\begin{array}{l}\text { Age } \\
\text { (year) }\end{array}$ & $\mathrm{N}$ & $\begin{array}{c}\text { Prevalence } \\
(\%)\end{array}$ & $95 \%$ CI \\
\hline $0-5$ & 58 & 13.8 & $6.5-25.9$ \\
$6-10$ & 114 & 33.3 & $24.9-42.8$ \\
$11-15$ & 127 & 66.1 & $57.1-74.1$ \\
$16-20$ & 104 & 76.9 & $67.4-84.3$ \\
$21-25$ & 79 & 84.8 & $75.5-91-5$ \\
$26-30$ & 62 & 90.3 & $79.4-96.0$ \\
$31-35$ & 69 & 91.3 & $81.3-96.4$ \\
$36-40$ & 57 & 91.9 & $81.4-96.9$ \\
$>40$ & 272 & 96.6 & $93.5-98.3$ \\
\hline Total & 947 & 75.6 & $72.7-78.3$ \\
\hline
\end{tabular}

CI: confidence interval.

The prevalence of HAV infection was higher in urban communities $(84.8 \%$; 95\% CI: 80.5-88.3) when compared with the rural ones $(70.3 \%$; $95 \%$ CI: 66.4-73.9). Of the 716 individuals who were exposed to HAV, the presence of IgM anti-HAV was analyzed in $702(98 \%)$ and only $4(0.6 \%)$ subjects were positive. Three of them have lived in rural communities (Furnas dos Dionísios and Furnas da Boa Sorte) and the last one in an urban community (São Benedito).

Epidemiology studies have been useful to evaluate the efficiency of public health strategies in general population or specific populations groups. Thus, the HAV seroprevalence studies provide the actual epidemiological pattern of this infection in a specific population, which constitute a useful approach to evaluate the present or future improvement in sanitation standards. The present study represents the first investigation of HAV infection in Afro-Brazilian isolated communities. A high overall prevalence $(75.6 \%)$ was found, when compared with that observed in general population (55.7\%) in South and Southeast regions. Nevertheless, this rate was similar to that obtained in Northeast region (76.5\%), but lower than the prevalence reported in Northern region of Brazil (92.8\%) (Clemens et al. 2000).

By the age of 10 years, one third of the children had seroconvert to HAV. This frequency was similar to those observed in São Paulo (28.1\%) (Focaccia et al. 1998) and Rio de Janeiro (34.7\%) (Vitral et al. 1998), but was lower than rates showed in Middle west region of Brazil such as in children in Goiânia city (69.7\%) (Queiroz et al. 1995), Goiás, and Peixoto de Azevedo (86.4\%), Mato Grosso (Assis et al. 2002). This prevalence was still lower when compared with those found in children with low socioeconomic status in Southeast and South regions (53 to 90\%) (Abuzwaida et al. 1987, Ferreira et al. 1996, Zago-Gomes et al. 2005). In Northern Brazil, higher rates were also reported for this age group (7090\%) (Bensabath et al.1987, de Paula et al. 2001).

Although some studies showed that urban populations have lower rates of HAV infection than rural populations 
(Barzaga 2000, Tufenkeji 2000, Arankalle et al. 2001), in this study urban communities had higher rate of HAV exposure than rural communities (84.8 versus $70.3 \%$ ). Similarly, Almeida et al. (2006) found a higher HAV prevalence in urban $(87.4 \%)$ when compared with rural $(79.7 \%)$ area in the settlement of Cavunge, a semi-arid region of the state of Bahia, Northeastern of Brazil. Furthermore, in the present investigation, both populations were selected from low-income communities. Subjects from rural areas do not have adequate environmental sanitation facilities; they use water from rivers for washing and drinking purposes as well as for their personal hygiene. The urban communities are located in small cities or outskirts of metropolitan regions where sanitation conditions are still poor provided, and environmental sanitation project do not exist yet or it is under construction. In addition to the poor sanitation facilities and hygiene conditions in this population, their houses are located close to each other and the high population density in low-income urban communities may contribute to the HAV dissemination.

In spite of low income, low educational level, and inadequate environmental conditions, the results of this study point out an intermediate endemicity of HAV infection in some Afro-Brazilian isolated communities in Central Brazil. Besides improvements in educational and sanitary conditions in these communities, vaccination programs against hepatitis A could be considered as an important strategy to prevent this infection.

\section{ACKNOWLEDGEMENTS}

To the important contributions of many health care workers throughout all Afro-descendant communities of the state of Mato Grosso do Sul, to Clarice P Machado, Edy F Pereira, Eva Faustino, Gisele F Bonfim, Hilda G Freitas, Kátia MB Lima, Maria Helena Bicudo, and Renata Aloise for their assistance.

\section{REFERENCES}

Abuzwaida ARN, Sidoni M, Yoshida CFT, Schatzmayr HG 1987. Seroepidemiology of hepatitis A and B in two urban communities of Rio de Janeiro, Brazil. Rev Inst Med Trop São Paulo 29: 219-223.

Almeida D, Tavares-Neto J, Queiroz-Andrade M, Dias C, Ribeiro T, Silva F, Silva-Araújo J, Tatsch F, Paraná R 2006. Aspectos sociodemográficos da soprevalência de marcadores do vírus da hepatite A no povoado de Cavunge, região do semi-árido do Estado da Bahia. Rev Soc Bras Med Trop 39: 76-78.

Arankalle VA, Chandha S, Chitambar SD, Walimbe AM, Chope LP, GAndhe SS 2001 Changing epidemiology of hepatitis A and hepatitis E in urban and rural India (1982-98). J Viral Hepat 8: 293-303.

Assis SB, Souto FJD, Fontes CJF, Gaspar AMC 2002. Prevalência da infecção pelos virus das hepatitis A e E em escolares de um município da Amazônia Mato-grossense, Brasil. Rev Soc Bras Med Trop 35: 155-158.

Barzaga NG 2000 Hepatitis A shifting epidemiology in SouthEast Asia and China. Vaccine 18: S61-S64.

Bensabath G, Hadler SC, Soares MCP, Fields H, Maynard JE 1987. Caracteristicas sorologicas y epidemiologicas de la hepatitis virica aguda en la cuenca amazonica del Brasil. Bol Of Sanit Panam 103: 351-362.

Clemens SA, da Fonseca JC, Azevedo T, Cavalcanti A, Silveira TR, Castilho MC, Clemens R 2000. Hepatitis A and hepatitis B seroprevalence in 4 centers in Brazil. Rev Soc Bras Med Trop 33: 1-10.

de Paula VS, Arruda ME, Vitral CL, Gaspar AM 2001. Seroprevalence of viral hepatitis in riverine communities from Western Region of the Brazilian Amazon Basin. Mem Inst Oswaldo Cruz 96: 1123-1128.

Ferreira CT, Silva GL, Barros FC, Ferreira-Lima J 1996. Soroepidemiologia da hepatite A em dois grupos populacionais economicamente distintos de Porto Alegre. Gastroenterol Endosc Dig 15: 85-90.

Focaccia R, da Conceição OJG, Sette Jr H, Sabino E, Bassit L, Nitrini DR, Lomar AV, Lorenço R, Souza FV, Kiffer CRV, Santos EB, Gonzales MP, Sáez-Alquézar A, Riscal JR, Fisher D 1998. Estimated prevalence of viral hepatitis in the general population of the municipaly of São Paulo, measured by a serologic of a stratified, randomized and residence-based population. BJID 2: 269-284.

Jacobsen KH, Koopman JS 2004. Declining hepatitis A seroprevalence: a global review and analysis. Epidemiol Infect 132: 1005-1022.

Lavanchy D 2002. Public health measures in the control of viral hepatitis: a World Health Organization perspective for the next millennium. J Gastroenterol Hepatol 17: S452-S 459.

Queiroz DA, Cardoso DD, Martelli CM, Martins RM, Porto SO, Borges AM, Azevedo MS, Daher RR 1995. Risk factors and prevalence of antibodies against hepatitis A virus (HAV) in children from day-care centers, in Goiânia, Brazil. Rev Inst Med Trop São Paulo 37: 427-433.

Santos DCM, Souto FJD, dos Santos DRL, Vitral CL, Gaspar AMC 2002. Seroepidemiological markers of enterically transmited viral hepatitis $\mathrm{A}$ and $\mathrm{E}$ in individuals living in a community located in North area of Rio de Janeiro, Brazil. Mem Inst Oswaldo Cruz 97: 637-640.

Tanaka J 2000. Hepatitis A shifting epidemiology in Latin America. Vaccine 18: S57-S60.

Tapia-Conyer R, Santos JI, Cavalcanti AM, Urdaneta E, Rivera L, Monterola A, Potin M, Ruttiman R, Kido JT 1999. Hepatitis A in Latim América: a changing epidemiologic pattern. Am J Trop Med Hyg 61: 825-829.

Tufenkeji H 2000. Hepatitis A shifting epidemiology in the Middle East and Africa. Vaccine 18: S65-S67.

Vitral CL, Gaspar AMC, Souto FJD 2006. Epidemiological pattern and mortality rates for hepatitis A in Brazil, 1980-2002 A Review. Mem Inst Oswaldo Cruz 101: 119-127.

Vitral CL, Yoshida CFT, Lemos ERS, Teixeira CS, Gaspar AMC 1998. Age-specific prevalence of antibodies to hepatitis A in children and adolescents from Rio de Janeiro, Brazil, 1978 and 1995. Relationship of prevalence to environmental factors. Mem Inst Oswaldo Cruz 93: 1-5.

Zago-Gomes MP, Stantolin GC, Perazzio S, Aikawa KH, Gonçalves CS, Pereira FE 2005. Prevalence of anti-hepatitis A antibodies in children of different socioeconomic conditions in Vila Velha, ES. Rev Bras Med Trop 38: 285-289. 